\title{
Basic Capital in the Egalitarian Toolkit?
}

\begin{abstract}
Under a basic capital grant policy (BC), every citizen receives a large capital grant as a right, typically in their early adulthood. Is BC part of the institutional framework of a just economy? Starting from John Rawls's discussion of just economic systems, the paper clarifies Rawls's reasons for thinking we need to complement welfare state policies with property-owning democracy and/or liberal socialist policies. It then seeks to clarify the grounds specifically for BC as a particular policy of the property-owning democracy type, and considers in depth what it adds to a policy of basic income (a uniform, universal and unconditional income grant paid to all, possibly in some part as a share of the return on publicly-owned wealth).
\end{abstract}

Keywords: egalitarianism, property-owning democracy, welfare state, basic capital, basic income.

Word count (without abstract, keywords and word count): 8712.

\section{Introduction}

In recent years, liberal thinkers, notably Bruce Ackerman and Anne Alstott, have argued for a scheme of basic capital (BC) through which all citizens receive in early adulthood a significant capital sum to use according to their discretion. ${ }^{1}$ The $\mathrm{BC}$ proposal has almost certainly had some impact on public policy, being one of the ideas that contributed in the UK to the establishment of the Child Trust Fund. ${ }^{2}$ Although this policy was abolished in 2010 as part of the UK government's initial austerity drive, there remains international interest in this idea. ${ }^{3}$ Should BC be included in our understanding of a just economic system? What contribution or contributions (if any) does it specifically make to the achievement of social justice? 
$\mathrm{BC}$ can be seen as one expression of a broader institutional ideal of what John Rawls calls 'property-owning democracy'. ${ }^{4}$ To begin our analysis, therefore, I begin in section 1 with a discussion of why Rawls regards property-owning democracy (and what he terms 'liberal socialism') as superior to welfare state capitalism in achieving social justice. Following Martin O’Neill, and drawing also on the arguments of Ben Jackson and Christian Schemmel, I reframe the issue in terms of what we may call, borrowing a term from Elizabeth Anderson, the egalitarian toolkit ${ }^{5}$ : Why does Rawls think that justice requires us to employ policy and institutional tools of the property-owning democracy kind as well as those we associate with the welfare state? Here, and throughout the paper, I do not take Rawls's theory of justice as necessarily definitive, but rather as one helpful source of insight into the limitations of welfare state policies and the potential advantages of policies and institutions that directly address the underlying distribution of assets.

In section 2 I next discuss the adequacy of the property-owning democracy tools Rawls proposes in light of the motivation for them. Rawls's own discussion puts a great deal of emphasis on a particular form of inheritance tax. Rawls expects too much of this one tool, and so I think we must consider other tools. These include what I term worker ownership and citizen ownership schemes. The latter include the idea of a Citizens' Trust which provides each citizen with an inalienable share of the return on society's productive assets. This policy, a form of basic income, has some clear attractions, so much so that one might wonder why it is important to go further and ensure that all citizens also have wealth holdings of their own.

This sets the stage for section 3 which explores the arguments specifically for BC. Important arguments for BC, building on Rawls's concerns without being necessarily tied specifically to his theory of justice, appeal to the related values of equality of opportunity and personal independence. I give particular attention here to an argument developed by Bruce Ackerman and Anne Alstott in their case for BC, the citizen's interest in adequate 
opportunity for ambition formation: in being able to approach life ambitiously, meaningfully posing and exploring the question 'What do I want to do with my life?' In developing the argument for BC, I consider what, if anything, a policy of this kind adds to a Citizens' Trust or, more generally, the payment of a basic income (a uniform, universal and unconditional income grant). Section 4 concludes.

\section{Property-owning democracy in the egalitarian toolkit}

In the Preface to the revised edition to A Theory of Justice, John Rawls emphasises that his conception of justice strongly favours property-owning democracy over welfare state capitalism. He draws out the contrast between the two as follows:

'...the background institutions of property-owning democracy, with its system of (workably) competitive markets, tries to disperse the ownership of wealth and capital, and thus to prevent a small part of society from controlling the economy and indirectly political life itself. Property-owning democracy avoids this, not by redistributing income to those with less at the end of each period, so to speak, but rather by ensuring the widespread ownership of productive assets and human capital...at the beginning of each period....The idea is not simply to assist those who lose out through accident or misfortune (although this must be done), but instead to put all citizens in a position to manage their own affairs and to take part in social cooperation on a footing of mutual respect under appropriately equal conditions. ${ }^{6}$

More precisely, as Samuel Freeman explains, Rawls distinguishes a range of different economic systems and considers their consistency with his preferred conception of social justice. ${ }^{7}$ Laissez-faire capitalism and centrally planned state socialism are both ruled out as violating core requirements of social justice. Welfare state capitalism is more acceptable in terms of justice than either of these, but nevertheless is held by Rawls to fall short of what justice demands. Justice can be satisfied, Rawls argues, either by the aforementioned property-owning democracy or by what Rawls terms liberal socialism. Where both of these differ from welfare state capitalism is in their attention to the background ownership and

control of assets. Welfare state capitalism is understood by Rawls to take a highly unequal distribution of productive assets (including human capital) as a given, and then to ameliorate the inegalitarian effects of this through income transfers. Under liberal socialism, by contrast, 
inequality in asset ownership is tackled through a degree of public ownership of the means of production, though the market remains the primary means of determining the allocation of resources. Under property-owning democracy, productive assets remain largely in private hands, but a policy framework exists to create and sustain a broadly egalitarian distribution of these assets. In the case of both liberal socialism and property-owning democracy, the greater degree of underlying asset egalitarianism, relative to welfare state capitalism, means that there is less need for compensatory income transfers to achieve distributive objectives. Rawls does not think there is necessarily much, if anything, to choose between liberal socialism and property-owning democracy in general, so far as social justice is concerned, but that local circumstances, including national histories and traditions, might make one more appropriate than the other. ${ }^{8}$ He assumes that for his audience property-owning democracy is the 'better known' possibility.

In recent years, Rawls's preference for property-owning democracy (and liberal socialism) over welfare state capitalism has been the subject of increased discussion. ${ }^{9}$ Much of the discussion has focused on the case for property-owning democracy as against welfare state capitalism. But another question which I think has begun to emerge is whether it is actually helpful to present the choice of 'economic system' in terms of a choice between these discrete alternatives - welfare state capitalism, property-owning democracy, liberal socialism and so on - at all.

First, we should be wary of setting up too stark an opposition between liberal socialism and property-owning democracy. Rawls derived his ideas about property-owning democracy from the British economist, James Meade, in particular from his 1964 book, Efficiency, Equality and the Ownership of Property. ${ }^{10}$ In his account of what he calls a 'partnership economy' in his later writings, however, Meade presents a sketch of an economic system that combines elements of what Rawls would call liberal socialism and 
property-owning democracy. ${ }^{11}$ (In particular, it includes a version of the Citizens' Trust proposal that I shall discuss below.) Moreover, as Ben Jackson emphasises in his historical overview of the idea of property-owning democracy, in the 1964 text which Rawls cites, Meade views trade unionism, the welfare state, public ownership and property-owning democracy as 'four ideal types that can all be drawn on when designing egalitarian social institutions. In any actually existing democratic polity, egalitarians would be best advised to pursue a plurality of egalitarian strategies, varying the emphasis between each of the elements according to contingent political circumstances. ${ }^{, 12}$ Indeed, as Paul Weithman has pointed out, Rawls himself does not treat liberal socialism and property-owning democracy as mutually exclusive, referring to 'many intermediate forms'. ${ }^{13}$

As Martin O'Neill argues, there is also a danger in our investing too much in the contrast between welfare state capitalism and property-owning democracy (or liberal socialism). One issue here, noted by O'Neill, is that Rawls's conception of property-owning democracy obviously includes significant welfare state elements, e.g., public education and health-care. ${ }^{14}$ A related issue, also noted by O’Neill and discussed in an important paper by Christian Schemmel, is that Rawls's contrast seems to work with a rather narrow conception of the welfare state. This might lead Rawls to overstate the contrast between welfare state capitalism and property-owning democracy (which, as said, actually has a substantial welfare state element). ${ }^{15}$

O’Neill concludes that: '...each of these Rawlsian regimes represents an amalgam of possible policies and institutional arrangements. Accordingly, plausible institutional and policy menus will typically draw from across these Rawlsian regimes... ${ }^{, 16}$ One way of taking on board O'Neill's point, perhaps, is to think of property-owning democracy, liberal socialism and the welfare state as referring to specific sets of tools in what we might call, echoing Elizabeth Anderson, an egalitarian toolkit. The question of just institutional design 
can then be conceived as a question of what combination or combinations of liberal socialist, property-owning democratic and welfare state (and other) tools will work to achieve social justice. ${ }^{17}$ Rawls's own acknowledgement of 'intermediate forms', combining elements of property-owning democracy and liberal socialism, shows that Rawls himself perhaps was not interested in investing too much in the idea of (choice between) distinct regime types.

The point or points Rawls is making in the above, quoted passage can still be appreciated, however, as criticisms of relying too exclusively on certain tools in the welfare state part of the egalitarian toolkit; or, stated more positively, as suggesting why it is necessary also for us to rummage about creatively in the property-owning democratic (and, perhaps, liberal socialist) areas of the toolkit. Looking at the passage quoted above, and at Rawls's lengthier discussion of economic structures in sections 42 and 43 of A Theory of Justice, we can identify at least three motivations for considering these parts of the toolkit.

The first motivation is to prevent oligarchy: to prevent an economic elite having so much wealth it can control the economy and 'indirectly political life itself.' Martin O'Neill points out that it might not be necessary to reduce inequality in the distribution of wealth to prevent political domination by the rich if we can stop the rich translating wealth into political power through such things as campaign finance laws and the like. ${ }^{18}$ However, I think it is an open empirical question as to how effective such measures by themselves will be. It might be that a robust approach to the problem requires a range of measures including some degree of direct regulation of wealth holdings, setting some upper limit on how much wealth any individual may hold.

A second Rawlsian motivation, not explicit in the quoted passage but evident elsewhere in Rawls's text, is 'fair equality of opportunity'. The thesis here is that inequality in financial inheritances, correlated with family social class, gives those from more affluent social classes an advantage in competing for jobs and economic positions over those of 
similar ability and motivation from less affluent classes. To equalise opportunity, it is necessary to limit the intergenerational transfer of large concentrations of wealth and to encourage a wider dispersion of wealth holdings.

A third motivation, indicated in the quoted passage, is what one might term personal independence. This is the idea Rawls seems to be conveying when he speaks of individuals being in a position to 'manage their own affairs'. Holding at least some minimum amount of wealth of one's own enables the individual to more effectively take control of their life: to be less dependent on the goodwill of others and to strike out in their own way. One aspect of this very broad idea of personal independence will feature prominently below in discussing the case for BC.

These are some motivations for why we ought to be interested in exploring the property-owning democracy (and liberal socialist) parts of the egalitarian toolkit. In the next section we will consider what kinds of things might be in this toolkit, looking at the respective strengths and weaknesses of specific tools in terms of these values. In section 3, we will then consider in more depth why $\mathrm{BC}$ in particular might be a useful item in the toolkit.

\section{What's in the property-owning democracy part of the toolkit?}

The property-owning democracy part of the toolkit is that of set of tools which seek to promote a wider, more equal ownership of privately-held assets. The thesis is that by setting ceilings and floors to the distribution of wealth - and we mean wealth here, rather than income - these measures will advance the ethical concerns sketched towards the end of the previous section: prevention of oligarchy; fair equality of opportunity; and personal independence.

In Rawls's discussion much emphasis is placed on the taxation of wealth transfers: the government 'imposes a number of inheritance and gift taxes, and sets restrictions on the 
rights of bequest'. ${ }^{19}$ Following Meade, Rawls suggests that the tax 'might be applied at the beneficiary's end' 20 'Doing this,' Rawls claims, 'would encourage the wide dispersal of property which is a necessary condition, it seems, if the fair value of the equal [political?] liberties is to be maintained' ${ }^{21}$

The basic idea is to tax the transfer of wealth across generations. However, this can be designed in a number of different ways. For example, in the UK at present so-called 'inheritance tax' is a tax placed on the estates of people at death. (Gifts made within a certain period before death are counted as part of the estate.) The tax varies according to the size of the estate. Alternatively, as Rawls suggests, following Meade, one can tax not the estate but the amount an individual receives. A further refinement of this idea is to vary the tax according to how much wealth the individual already has or, in a more discriminating version, according to how much wealth the individual has already received by means of inheritance, bequest or gifts. This gives us the proposal for a lifetime accessions tax. Each individual might be allowed to receive up to a certain amount from inheritances and gifts without incurring any tax (e.g., up to $£ 100,000$ ). Then, anything received over this level is liable to tax, perhaps at a progressive rate. In Meade's view, this form of tax has the merit of encouraging those with wealth to give away to spread their wealth across individuals and, in particular, to direct it towards those who have not yet received much by way of gift or inheritance. In this manner, the wealthy individual can minimise the amount of their wealth which is taken in tax. If this incentive is strong enough, then the tax will not only work to break down large concentrations of wealth across the generations but will also work indirectly to ensure everyone inherits at least some wealth. The policy simultaneously helps place a ceiling on wealth holdings and provide a floor to them. This can be expected to further all of the ethical concerns sketched above. 
It is important, however, to acknowledge the limitations of this policy tool by itself. We may note first that since the tax is on gratuitous transfers of wealth, it does not actually impose any kind of ceiling on vast wealth holdings which the individual acquires by themselves. In this respect it does not fully tackle, for example, the problem of very wealthy individuals potentially buying their way into political influence. Also, as critics such as Jon Elster have argued, we probably should not expect too much from this one policy in terms of ensuring that everyone ends up with some inherited wealth. ${ }^{22}$ The tax provides some incentive to give wealth away to those who have yet to receive any wealth by way of gift, bequest or inheritance, but this incentive mechanism alone is almost certainly too weak to ensure that all citizens have some wealth of their own. To this extent, the policy is not likely, by itself, to deliver the gains we might want in terms of fair equality of opportunity and personal independence. If we want to achieve an egalitarian dispersion of privately-held wealth, then we are almost certainly going to have to combine this tool with others.

What else, then, might be in the property-owning democracy part of the egalitarian toolkit?

One familiar set of proposals concern employee or worker ownership. One picture of a property-owning democracy envisions an economy in which many enterprises are owned or partly owned by those who work in them, e.g., an economy-wide system of worker cooperatives. Various policies can be used to promote worker ownership. One interesting proposal, for example, is to link worker ownership to profit-sharing. According to advocates of profit-sharing as traditionally conceived, capital should be properly allowed a certain normal rate of return, a 'capital wage' (e.g., of 5\%). Any return over and above this should then be shared between labour and capital according to some ratio (e.g., a 50/50 split). ${ }^{23}$ Labour's profit share could be invested in productive assets. Over time, as successive profit shares are invested in this way, workers are able to build up ownership stakes in their own 
(and/or in other) firms. ${ }^{24}$ Other policies include tax incentives to firms to give their workers shares in the company and giving workers favourable terms to purchase an enterprise's assets when these are moved from the public to the private sector (if that is appropriate). Worker coops can be supported more generally by favourable tax treatment or credit.

By promoting worker ownership, these policies arguably go further than the lifetime accessions tax in spreading productive assets. As such, they probably also have a place in the egalitarian toolkit.

Nevertheless, these tools also have their limitations. One objection, of course, is that if we encourage workers to hold assets in the firms in which they work, then this involves an undesirable concentration of risk. If the firm gets into difficulties, the workers in question stand to lose not only their jobs and wage income but also their wealth. ${ }^{25}$ More generally, this model of worker ownership does not directly address inequalities between firms. ${ }^{26}$ To meet this sort of objection, worker ownership schemes must aim at helping workers build stakes not only in their own firms but in the wider economy. However, even in this case, worker ownership schemes still have an important limitation. This is that they are aimed, precisely, at workers - that is to say, at paid employees. There are, however, many citizens who are not workers (in this sense). They might be involuntarily unemployed. They might have carer responsibilities. They might have a health condition or a disability that makes it difficult to be in employment. Policies that aim to spread wealth to workers do not spread wealth directly to people in these categories. In this respect, they remain somewhat exclusionary.

To overcome this limitation, we seem to need policies that help establish claims to wealth on the basis of citizenship rather than being a worker. ${ }^{27}$ One way of linking wealth directly to the status of citizenship is of course provided by basic capital (BC). Under this proposal, every citizen is to receive a lump-sum capital grant in early adulthood to use as they please. An example is the proposal by Bruce Ackerman and Anne Alstott that every citizen in 
the US receive a grant of some $\$ 80,000$ on reaching the age of $18 .^{28}$ Frequently, the proposal is linked with some form of inheritance tax, the idea being to use this tax as a revenue source for the universal capital grant. A variant on the proposal would make the grant available only for those growing up in households with wealth below some threshold level. This threshold could be set quite high, however, so that a majority of young people receive a $\mathrm{BC}{ }^{29}$

There is, however, another model of how to link citizenship to wealth. This is what we might call the Citizens' Trust model. This is really part of the liberal socialist part of the toolkit, rather than the property-owning democratic part, but it makes sense to discuss it here. The proposal is to create a public investment fund and to endow each citizen with a right to a share of the annual return on the fund's investments. The proposal forms an important part of Meade's model of a 'partnership economy'. ${ }^{30}$ In his sketch of 'Agathotopia' (the 'good place'), Meade envisages that the community owns up to $50 \%$ of the nation's stock of productive assets. The state does not seek to own and run particular firms or industries but owns a portfolio of assets across the economy. The return on this fund is then distributed to citizens as a 'social dividend'. Such a fund can be established by investing budget surpluses or through schemes of capital dilution under which firms over a certain size are required to issue new shares each year to a community-owned fund or funds. A real-world example of a public fund which provides an annual dividend for all citizens in the proposed manner is the Alaska Permanent Fund. Some of the revenues raised from the taxation of minerals extraction have been used by the Alaskan state to create an ongoing investment fund. This produces an annual return which is distributed to all Alaskan citizens as a cash dividend. ${ }^{31}$

The Citizens' Trust proposal differs fundamentally from BC in that it does not give each citizen direct access to a capital sum. In this respect, it does not meet the objective of ensuing everyone wealth of their own. However, what it does do is to ensure that each citizen has a claim on the income from a proportion of their society's assets. Moreover, this claim is 
not conditional on work or labour market status. In this way, the Citizens' Trust does do at least some of what universal wealth holding would do: it secures for each citizen an income that is independent of the sale of their labour-power and which is also invulnerable to bureaucratic discretion. This financial independence, of course, in turn grounds an ability to live more independently: one can afford to follow one's own way to a greater extent precisely because one is less economically dependent on the goodwill of an employer, spouse or welfare state official. ${ }^{32}$ In this way, the Citizens' Trust can make an important contribution to enabling citizens to 'manage their own affairs' and to ensuring that when they cooperate economically, they do so 'under appropriately equal conditions'.

Under BC citizens do get direct access to a capital sum. If they so choose, they can just invest the sum and then enjoy an annual return on it in the manner of a social dividend. But they are also able to dip into the principal itself. One can see immediately the risk this poses. Citizens might lose their capital, either through imprudent use or through bad luck. The annual dividend it would have provided, independent of the sale of labour-power, is then lost, and this can be expected, other things being equal, to reduce their financial independence. The individual then becomes that much more dependent on the goodwill of employers, spouses and others.

In view of this drawback, one might ask: What is the countervailing upside to allowing the citizen access to the capital itself? Why should we seek a BC rather than (just) a Citizens' Trust scheme?

\section{3. 'Beginning the world': contributions of basic capital}

In their argument for a targeted BC programme, Darrick Hamilton and William Darity Jr. point to the various advantages that come with wealth:

'Wealthier families are far better positioned to finance elite independent school and college education, access capital to start a business, finance expensive medical procedures, reside in high amenity neighbourhoods, lower health hazards, etc.; exert political influence through campaign financing; purchase better counsel if confronted with the legal system, 
leave a bequest, and/or withstand financial hardship resulting from any number of emergencies. 33

The extent of these advantages depends to some extent on the nature of the welfare state (e.g., in terms of access to education and health-care), but even a generous welfare state will likely not cancel the advantages that accrue to those with wealth. Indeed, this is precisely one reason why it is important to look to the tools in the property-owning democracy and liberal socialist parts of the egalitarian toolkit. Consider, in particular, the advantages that accrue in terms of accessing education or setting up a business. ${ }^{34}$ When wealth is distributed very unequally, these advantages impact directly and negatively on society's ability to achieve fair equality of opportunity. In order to get closer to fair equality of opportunity, it does not seem enough that citizens have secure access to a regular return on capital as is provided under the Citizens' Trust proposal. They must also have access to capital itself. Citizens must not only be able to enjoy a return on investments, but be able to finance their own, chosen investments. This is what BC enables. ${ }^{35}$

In doing this, however, $\mathrm{BC}$ not only contributes to fair equality of opportunity. It also makes an important contribution to one specific aspect of personal independence. This is hinted at in one of the earliest BC proposals, that put forward by Tom Paine in his 1797 work, Agrarian Justice. Here is the language Paine uses to introduce the proposal:

‘...A PLAN FOR MELIORATING THE CONDITION OF MAN, BY CREATING IN EVERY NATION A NATIONAL FUND,

To pay to every Person, when arrived at the Age of TWENTY-ONE YEARS, the Sum of FIFTEEN POUNDS Sterling, to enable HIM or HER to begin the World!' (Paine, 1995 [1797], p. 409).

For Paine, our adult lives are not things we that we should shuffle or drift into. We should be in a position to begin the world. This is an immensely evocative phrase. It conveys, I think, a sense of it being appropriate to launch into adult life with a sense of creative openness and possibility. 
This idea is central to the argument that Ackerman and Alstott make for their version of the BC proposal. 'If a liberal society is to vindicate the value of individual autonomy,' they write, 'it must consider carefully the conditions under which young adults confront basic choices. ${ }^{36}$ With this emphasis on confronting 'basic choices', their argument foregrounds what we may term the citizen's interest in adequate opportunity for ambition formation. This is an interest in being able to approach one's adult life with ambition, not necessarily in the narrow materialistic or positional senses of the term. It means that one can meaningfully pose and explore the question: 'What do I want to do with my life?'

According to Ackerman and Alstott a lack of assets in early adulthood compromises one's opportunity for ambition formation. As they put it: '...just at the moment we expect young adults to make responsible life-shaping decisions, we do not afford them the resources they need to take a responsible long-term perspective.... ${ }^{37} \mathrm{BC}$ is a way of rectifying this situation: '[s]takeholding is built on...the imperative need to redeem the liberal promise, made to each citizen, of genuine freedom to shape his or her life. ${ }^{38}$

There seem to be at least two ways in which, according to Ackerman and Alstott, a lack of assets impairs opportunity for ambition formation. One is what we may term the distraction effect. A lack of assets means that a young adult is immediately caught up in the struggle to make ends meet. This limits their ability to pose and explore the question of what they would like to do with their life. The distraction effect is arguably what Ackerman and Alstott are getting at when they speak of how: 'Forced to put bread on the table...almost all young adults are squeezed into short-term thinking..., ${ }^{39}$ Second, there is what we might call the horizons effect. Even if one does devote some time to thinking about one's life goals, a lack of assets is likely to mean that one takes a relatively conservative view of what these might be. Why think ambitiously if one lacks the resources needed to back up an ambitious life-plan? The horizons of one's deliberation about the good life are narrowed. This is what 
Ackerman and Alstott are referring to when they write that '...a propertyless person lacks crucial resources needed for self-definition....He can never enjoy the luxury of asking himself what he really wants out of life... ${ }^{40}$ Holding assets in early adulthood - and having full access to the principal as well as the returns on the capital sum - can be expected to counter these two distraction and horizon effects and, thereby, work to secure adequate opportunity for ambition formation.

Of course, this line of argument assumes that citizens do have an underlying interest in opportunity for self-definition in their lives. In Rawls's terms, it presupposes something like the citizen's interest in being able to frame and revise and rationally to pursue a conception of the good life. ${ }^{41}$ Ambition formation is integral to the framing (and perhaps also, to some degree, revising) of one's conception of the good life. The argument also supposes that there is something particularly important about opportunity for ambition formation in early adulthood. As I understand it, the claim here is that early adulthood is a key strategic point in someone's life in terms of their opportunity to lead a life with self-definition. If people lack opportunity for ambition formation at this stage then, as the distraction and horizon effects take their toll, they will be at risk of drifting into relatively unambitious ways of life that then limit their prospects for the rest of their lives. A lack of adequate opportunity for ambition formation in early adulthood implies, or at least increases the risk of, a lack of adequate opportunity for ambition formation throughout one's life. ${ }^{42}$ The argument, couched somewhat in Rawlsian terms, might be summarised as follows:

(1) All individuals have a fundamental interest in having an autonomous life; that is, a life in which they have the capacity to frame and revise their conception of the good.

(2) The interest in (1) is strongly affected by the degree to which individuals have opportunity for ambition formation in their early adult years.

(3) Therefore, individuals have a strong interest in having adequate opportunity for ambition formation in their early adult years.

(4) One condition for satisfying the interest in (3) is that individuals have some capital in their early adult years.

(5) Therefore, individuals have a strong interest in having some capital in their early adult years. $^{43}$ 
As presented, and as intimated above, the argument clearly rests on certain empirical premises. Step (2) of the argument, for example, makes an empirical claim about the significance of ambition formation in early adulthood to self-definition across one's life as a whole. Step (4) of the argument makes an empirical claim about the significance of capital to opportunity for ambition formation (in early adult years). I think both claims are plausible, but the success of the argument clearly does depend on relevant research showing that the respective empirical claims are correct.

One objection to step (4) of the argument is that while $\mathrm{BC}$ is perhaps one way to serve the interest in opportunity for ambition formation it is not the only way or necessarily the best way of doing so. One alternative, for example, is to give citizens subsidies for education or training. A proposal of this sort, however, can be challenged as arbitrarily channelling young people's ambitions in particular directions. If, for example, we use the resources that might finance a BC to finance a system of subsidies for education and training, how will this serve those young people who, perhaps quite reasonably, do not wish to acquire further education or training? What about those who would like to explore setting up a business or travelling the world to gain experience and knowledge ${ }^{44}$ In terms of liberal political values, proposals of this sort seem vulnerable to the objection that they are not sufficiently neutral between the different reasonable life-plans that citizens might choose to develop and pursue. One response to this neutrality objection is to add to the menu of things young adults can get finance to do. This points towards a policy that one might call 'use-restricted $\mathrm{BC}$ ' under which young adults in effect receive a voucher which can be used to access a range of options: higher education, training, setting up a business, putting a deposit on a house, and so on. In principle this is a reasonable policy. ${ }^{45}$ However, all things considered, I am not sure it is preferable to a straightforward BC. A straightforward BC is the most inclusive (and, 
therefore, neutral) policy of this kind, in terms of the kind of ambitions it can accommodate, and it carries less administrative cost and complexity than the use-restricted version of BC.

It might also be argued that an unconditional basic income will serve the interest in opportunity for ambition formation as well as, or even better than, $\mathrm{BC}{ }^{46}$ By basic income here we mean an income payment of the social dividend kind noted above: regular, not means-tested and independent of work. ${ }^{47}$ By giving people some financial independence from the labour market, a basic income can be expected to underpin some degree of reflection and experimentation as young people consider what they wish to do with their lives. Moreover, it will support this on an ongoing basis. Whereas BC can be lost in one go through imprudence or bad luck - what Ackerman and Alstott term 'stakeblowing' - a basic income is an ongoing payment over time and so can support a degree of reflection and experimentation over time.

Ackerman and Alstott are unimpressed with basic income as a means of supporting opportunity for ambition formation. They take the relevant comparison to be that between a $\mathrm{BC}$ of $\$ 80,000$ and a basic income providing an annual dividend of $5 \%$ of this sum, so around $\$ 4,000$ per year. They comment:

'...the small amounts dribbled out annually [under basic income] never really encourage the kind of sober reflection that stakeholding invites. It is just too easy to spend four thousand dollars a year [a basic income] on incidentals without ever confronting how the extra resources could help you reshape the larger contours of your life. ${ }^{48}$

One point to make here is that in this passage Ackerman and Alstott seem to step over a line from a concern to secure adequate opportunity for ambition formation to a concern to promote actual ambition formation. It is not simply that people should have real opportunity meaningfully to explore the question of the goals of their life, but that they should do this. Basic income is seen as deficient because it will stimulate less actual ambition formation. For some liberals, this argument will be too perfectionistic or characteristic of a 'comprehensive liberalism'; in other words, it also fails a test of state neutrality on the nature of the good life. 
It is possible, however, to reframe the point Ackerman and Alstott are making in a way that is less vulnerable to this neutrality-based objection. Here we can usefully return to the distraction and horizon effects which we distinguished above. The drawback in the basic income proposal is that it does not provide young adults with the capacity to marshal substantial resources in one go to support a new, potentially life-shaping project. In terms of the two effects distinguished above, it is consequently likely to be inferior to $\mathrm{BC}$ in combating the horizons effect of asset poverty. Precisely because you can dip into the principal of a large capital sum, $\mathrm{BC}$, in contrast to a basic income, enables young people to 'think big' about their plans, pushing forward the horizons of imagination and ambition. The point is not that young people will necessarily be more inclined to think big, but that they will at least have (more of) an opportunity to do so.

Now a basic income is also a $\mathrm{BC}$, of course, to the extent that citizens are allowed to convert their basic income into a lump-sum. If we introduce a basic income, either on the Citizens' Trust model or through the tax-benefit system (or a combination), and allow full convertibility of the basic income into capital through loans, then basic income will do the job we have been talking about. The question at issue here is then reposed as the question of how far, if at all, the state should allow such convertibility if there is a basic income.

As suggested by Philippe Van Parijs in his discussion of basic income, one way to approach this question is to ask what a person would agree to in this context as a matter of 'self-paternalism': that is, what level or kinds of limits on convertibility they would agree to as a way of best protecting their long-term interests. A reasonable person might foresee the dangers and risks involved in complete convertibility, for instance, and on this basis wish to impose on themselves a limit on how far they can convert a basic income into a lump-sum. This is the reasoning behind Van Parijs's preference for a basic income. ${ }^{49}$ However, it is by no means clear that a reasonable person would opt for a complete ban on convertibility. 
Looking ahead, they might anticipate the possibility that at some point in their life they might wish to be able to marshal substantial resources at once to support a new project. Allowing a modest degree of convertibility can arguably support this interest and, thereby, the interests in fair equality of opportunity and ambition formation, without unduly threatening the underlying security provided by a basic income. ${ }^{50}$ For reasons given above, it might be particularly important to allow this possibility in early adulthood, though, of course, the convertibility right does not have to be formally restricted or at all differentiated by age. On balance, therefore, a reasonable self-paternalism might well support a degree of convertibility of basic income into BC.

One weakness in asking what we think a 'reasonable person' would agree to in such a situation, however, is that we can easily just read our own preferences into the thought experiment. Rather than run the risk that the theorist merely reproduces their own attitudes through the hypothetical reasonable chooser, we should also try to find out what real people, our fellow citizens, think about these kinds of choices. In the case of $\mathrm{BC}$ we do, in fact, have some interesting evidence.

In 2003 the UK government introduced the Child Trust Fund (CTF), a policy under which all children were granted a small sum at birth which was then placed in an investment account on their behalf. (As noted above, the policy was effectively abolished in 2010.) Families could add to the accounts up to a ceiling of $£ 1,200$ each year. Once placed in the account, the savings could not be withdrawn until the child reached 18 when the accumulated sum would become theirs, to use as they wish. The policy had a modest BC element (the initial state-funded endowment) and was clearly intended to achieve a similar objective of ensuring all citizens some wealth of their own in early adulthood. In a research project aimed at exploring attitudes to these policies and how they might be further developed, Andrew Gamble and Rajiv Prabhakar explored young people's attitudes to capital endowment 
schemes. ${ }^{51}$ Using focus groups, Gamble and Prabhakar asked young people to reflect and comment on a range of possible policies. The three alternatives in effect were: a grant of $£ 1,000$ at 18 ; a grant of $£ 10,000$ at 18 ; or a grant of $£ 50,000$ at 18 (the latter intended to be equivalent to the sort of proposal made by Ackerman and Alstott). Summarising very crudely, the respondents in the focus groups were sceptical of both the small $(£ 1,000)$ and large $(£ 50,000)$ grants. They thought the small grant was too small to make much of a difference to people's planning and expected it to be used mostly to subsidise short-term consumption (e.g., having a holiday). However, they also felt that the large grant placed too much responsibility on people at this age. By contrast, the intermediate grant of $£ 10,000$ was seen as being large enough to make a difference to planning but also as not burdening people with too much responsibility.

Returning to the convertibility question, the results of the focus groups arguably support the hypothesis that a reasonable person would not want full convertibility of their basic income into BC. This is the implication, I think, of the firm rejection in the focus groups of a very large $\mathrm{BC} .{ }^{52}$ On the other hand, there was clear support for a (not too small) BC. This is consistent with the thesis that a reasonable person would choose some degree of convertibility of a basic income so as to be able to create, at their discretion, a BC. ${ }^{53}$

In summary, then, while a Citizens' Trust scheme gives citizens some of the advantages of wealth, there are others, related to fair equality of opportunity and personal independence, which are better provided by BC. The only way a Citizens' Trust scheme can offer these benefits is if we allow a degree of convertibility of the payments it provides into capital, in which case it in effect incorporates a form of BC. In policy terms, the argument here is not for a $\mathrm{BC}$ as a complete alternative to a Citizens' Trust, or to a basic income scheme more generally, but for a hybrid that includes a BC element (e.g., through making a basic income partly convertible). 


\section{Conclusion: $\mathrm{BC}$ in the egalitarian toolkit}

John Rawls argues that for a variety of justice-related reasons, summarised here in terms of preventing oligarchy, achieving fair equality of opportunity, and securing personal independence, we must seek to complement the institutions of the welfare state with other policies and institutions that act directly on the ownership and control of wealth. As I have expressed it here, we are invited to think in terms of an egalitarian toolkit and to consider what useful tools are to hand in the property-owning democracy and liberal socialist parts of the toolkit.

Useful tools here would seem to include forms of wealth transfer taxation such as the lifetime accession tax, schemes to promote worker ownership, and Citizens' Trust schemes which secure for each citizen a claim on the returns to publicly-owned assets. But BC also has its place in the toolkit. It has an important role to play in relation to fair equality of opportunity, for example, and in serving this value also serves to secure an important aspect of personal independence: the citizen's opportunity for ambition formation, her ability to approach adult life in a spirit of appropriate ambition. Today in nations like the UK and the USA, many young people start their adult lives with significant amounts of debt: a policy of negative basic capital, which arguably has the effect of constraining ambition formation, channelling it into narrowly instrumental, market-related, materialistic directions. Or else indebtedness risks crushing ambition formation altogether, discouraging people from thinking ambitiously for the long-term as they adjust to a life of employment (when jobs are available) in the service of long-term debt repayment. ${ }^{54} \mathrm{BC}$ belongs to an alternative vision: of a society where all citizens are genuinely able to 'begin the world'.

Notes: 
${ }^{1}$ B. ACKERMAN and A. ALSTOTT (1999), The Stakeholder Society (New Haven, Yale University Press).

2 R. PRABHAKAR (2008), The Assets Agenda: Principles and Policy (Basingstoke, Palgrave).

${ }^{3}$ See R. CRAMER and D. NEWVILLE (2009), Children's Savings Accounts: The Case for Creating a Lifelong Savings Platform at Birth as a Foundation for a "Save and Invest" Economy (Washington, D.C., New America Foundation) http://assets.newamerica.net/publications/policy/childrens_savings_accounts, accessed August 30 2013. The New America Foundation has repeatedly sought support in the Congress for an ASPIRE act to create a policy akin to the Child Trust Fund; see http://assets.newamerica.net/the aspire act. See also D. HAMILTON and W. DARITY JR. (2010), Can 'Baby Bonds' Eliminate the Racial Wealth Gap in Putative Post-Racial America?, Review of Black Political Economy 37, pp.207-216. For discussions of BC proposals and related ideas in Germany and France, see, respectively, G. GRÖZINGER, M. MASCHKE and C. OFFE (2006), Die Teilhabegesellschaft: Modell eines Neuen Wohlfahrstaates (Frankfurt, Campus), and CENTRE D'ANALYSE STRATEGIQUE (2007), Les Donations en Capital Pour les Jeunes (Paris, Centre d'Analyse Strategique).

${ }^{4}$ J. RAWLS (1999 [1971]), A Theory of Justice (Cambridge: MA, Harvard University Press), pp.xiv-xvi, 234-251.

5 E. ANDERSON (2008), Expanding the Egalitarian Toolbox: Equality and Bureaucracy, Aristotelian Society Supplementary Volume 82 (1), pp.139-160.

${ }^{6}$ Rawls, Theory of Justice, p.xv.

${ }^{7}$ S. FREEMAN (2007), Rawls (London, Routledge), pp.219-235.

${ }^{8}$ Rawls, Theory of Justice, pp.xv-xvi, 242.

${ }^{9}$ See M. O'NEILL and T. WILLIAMSON eds. (2012), Property-Owning Democracy: Rawls and Beyond (Oxford, Blackwell).

${ }^{10}$ J. MEADE (1964), Efficiency, Equality and the Ownership of Property (London, Allen and Unwin). Rawls references the book in Rawls, Theory of Justice, pp.241, 242, 245.

${ }^{11}$ J. MEADE (1989), Agathotopia: The Economics of Partnership (Aberdeen, University of Aberdeen).

12 B. JACKSON (2012), Property-Owning Democracy: A Short History, in O'Neill and Williamson, eds., Property-Owning Democracy, pp.33-52, specifically p.47.

${ }^{13}$ Rawls, Theory of Justice, p. 242.

${ }^{14}$ See M. O’NEILL (2012), Free (and Fair) Markets Without Capitalism, in O'Neill and Williamson, eds., Property-Owning Democracy, pp.75-100, specifically pp.91-93. 
${ }^{15}$ See O’Neill, Free (and Fair) Markets Without Capitalism, pp.91-93, and C. SCHEMMEL (forthcoming), How (Not) to Criticize the Welfare State.

${ }^{16}$ O’Neill, Free (and Fair) Markets Without Capitalism, p.92.

17 Another set of tools, which one risks overlooking within Rawls's typology of economic regime types, is the 'associative democracy' set. This includes trade unionism, community organizing and related forms of functional and interest representation designed to equalise power relations between interest groups. See in particular J. COHEN and J. ROGERS (1994), Associative Democracy (London, Verso) and A. TATTERSAL (2010), Power in Coalition: Strategies for Strong Unions and Social Change (New York, Cornell University Press).

${ }^{18}$ O’Neill, 'Free (and Fair) Markets Without Capitalism', pp.82-83.

${ }^{19}$ Rawls, Theory of Justice, p. 245.

${ }^{20}$ Rawls, Theory of Justice, p.245.

${ }^{21}$ Rawls, Theory of Justice, p.245.

22 J. ELSTER (1986), Comments on Krouse and McPherson, Ethics 97 (1), pp.146-53, specifically pp.147-148.

${ }^{23}$ S. WHITE (2009), 'Revolutionary Liberalism'? The Philosophy and Politics of Ownership in the Post-War Liberal Party, British Politics 4 (2), pp.164-187, specifically pp.170-172.

${ }^{24}$ See the discussion of the proposal for 'pancapitalism', originating in the milieu of French Gaullism, in White, 'Revolutionary Liberalism?', pp.171-172.

25 This point was made effectively by John Roemer in his comments to a seminar on 'Property-owning democracy', Department of Philosophy, New York University, May 2012.

${ }^{26}$ J. GUINAN and T. HANNA (2013), Democratising capital at scale: co-operative enterprise and beyond, http://www.opendemocracy.net/ourkingdom/joe-guinan-thomas-m-

hanna/democratising-capital-at-scale-cooperative-enterprise-and-beyon, accessed August 29 2013.

${ }^{27}$ Citizenship can and does of course also function as an exclusionary category. Insofar as rights to citizenship are not themselves specified justly, rights conditioned on citizenship will also be unjust. See A. SHACHAR (2009), The Birthright Lottery: Citizenship and Global Inequality (Cambridge: MA, Harvard University Press).

28 See Ackerman and Alstott, Stakeholder Society, and also B. ACKERMAN and A. ALSTOTT, 'Macro-Freedom', in B. ACKERMAN, A. ALSTOTT and P. VAN PARIJS (2006), Redesigning Distribution: Basic Income and Stakeholder Grants as Cornerstones for an Egalitarian Capitalism (London, Verso), pp.209-216.

${ }^{29}$ See Hamilton and Darity, Can 'Baby Bonds' Eliminate the Racial Wealth Gap in Putative Post-Racial America? Hamilton and Darity argue for a substantial capital endowment for 
children at birth with eligibility for, and the size of, the endowment depending on family wealth.

${ }^{30}$ Meade, Agathotopia.

${ }^{31}$ See K. WIDERQUIST and M. HOWARD (2012), Alaska's Permanent Fund Dividend: Examining its Suitability as a Model (Basingstoke, Palgrave). See also A. CUMMINE (2014), A Citizen's Stake in Sovereign Wealth Funds: The Management, Investment and Distribution of Sovereign Wealth, D.Phil thesis, Oxford University.

${ }^{32}$ This is an important argument for basic income. See, for example, D. RAVENTÓS (2007), Basic Income: The Material Conditions of Freedom (London, Pluto).

${ }^{33}$ Hamilton and Darity, Can 'Baby Bonds' Eliminate the Racial Wealth Gap in Putative PostRacial America?, p.210.

${ }^{34}$ On the importance of wealth to access credit markets under conditions of imperfect information, see K. HOFF (1998), Market Failures and the Distribution of Wealth: A Perspective from the Economics of Information, in S. BOWLES and H. GINTIS (1998), Recasting Egalitarianism: New Rules for Communities, States and Markets (London, Verso), pp.332-357.

${ }^{35}$ It might be argued that a social dividend from a Citizens' Trust scheme would also open doors in the way here envisaged because it could be used to help gain access to credit. I consider this possibility below.

${ }^{36}$ Ackerman and Alstott, Stakeholder Society, pp.34-35.

${ }^{37}$ Ackerman and Alstott, Stakeholder Society, p.35.

${ }^{38}$ Ackerman and Alstott, Stakeholder Society, p.93.

${ }^{39}$ Ackerman and Alstott, Stakeholder Society, p.35.

${ }^{40}$ Ackerman and Alstott, Stakeholder Society, p.191.

${ }^{41}$ J. RAWLS (1993), Political Liberalism (New York, Columbia University Press), pp.19, 30-32.

${ }^{42}$ Implicit in this argument, as in that of Ackerman and Alstott on which it is based, is the idea of a fair allocation of resources across the life-cycle. This relatively neglected aspect of justice is considered in depth in J. BIDADANURE (2014), Treating Young People as Equals: Intergenerational Justice in Theory and Practice, Ph.D thesis, University of York.

${ }^{43}$ See S. WHITE (2010), A Modest Proposal? Basic Capital vs. Higher Education Subsidies, British Journal of Politics and International Relations 12 (1), pp.37-55.

${ }^{44}$ I discuss this and related issues in White, A Modest Proposal? 
45 For proposals of this kind, see R. HAVEMAN (1988), Starting Even: An Equal Opportunity Program to Combat the Nation's New Poverty (New York, Simon and Schuster), D. NISSAN and J. LE GRAND (2000), A Capital Idea: Start-Up Grants for Young People (London, Fabian Society), and S. WHITE (2003), The Civic Minimum: On the Rights and Obligations of Economic Citizenship (Oxford, Oxford University Press).

${ }^{46}$ I am grateful to Erik Olin Wright for making this argument to me. A related argument for basic income, as a superior alternative to BC, is developed by Juliana Bidadanure on the basis of a theory of justice across life-cycle stages. See J. BIDADANURE (2014), 'Basic Income versus Basic Capital: An Intergenerational Perspective', paper presented at Summer School on 'Predistribution and Property-Owning Democracy', University of Minho, July 14-18 2014; and Bidadanure, Treating Young People as Equals, chapter 5.

47 See P. VAN PARIJS (1995), Real Freedom for All: What (if Anything) Can Justify Capitalism? (Oxford, Oxford University Press).

${ }^{48}$ Ackerman and Alstott, Stakeholder Society, pp.214-215. See also Ackerman and Alstott, 'Macro-Freedom'.

${ }^{49}$ Van Parijs, Real Freedom for All, pp.45-48. Van Parijs draws on G. DWORKIN (1971), Paternalism, in R. WASSERSTROM ed. (1971), Morality and the Law (Belmont: CA, Wadsworth), pp.107-126.

${ }^{50}$ Here I follow my argument in S. WHITE (2011), Basic Income vs. Basic Capital: Can We Resolve the Disagreement?, Policy and Politics 39 (1), pp.67-81. I also draw on Dworkin, Paternalism. See also Bidadanure, Treating Young People as Equals, chapter 5.

51 A. GAMBLE and R. PRABHAKAR (2006), Attitudes of young people towards capital grants, in W. PAXTON and S. WHITE with D. MAXWELL eds. (2006), The Citizen's Stake: Exploring the Future of Universal Asset Policies (Bristol, Policy Press), pp.107-119.

${ }^{52}$ It is perhaps worth noting that university tuition fees in the UK were much lower at the time of the focus groups than they are now. To keep pace with university tuition fees, a BC would now have to be in the region of $£ 25,000-£ 30,000$.

${ }^{53}$ I do not wish to claim too much here. The focus group evidence is far from decisive on the convertibility question. One reason is that the participants were not presented with a BC as being paid for out of a basic income stream they would otherwise have.

${ }^{54}$ In the UK context, see E. HOWKER and S. MALIK (2010), Jilted Generation: How Britain Has Bankrupted its Youth (London, Icon). I discuss this and related problems in the UK in a little more depth in S. WHITE (2012), Basic Capital: A Policy Whose Time Has Come...And Gone?, The Good Society 21 (1), pp.61-73, specifically pp.68-71. 